\title{
Phytochemical Profile and Total Antioxidant Capacity of Sempervivum ruthenicum Koch Hydroethanolic Extract
}

\author{
SEBASTIAN MIHAI ${ }^{1 *}$, DENISA DUMITRESCUㄹ, MADALINA ANA RADUCANU², IULIANA STOICESCU, VICTORIA BADEA ${ }^{2}$ \\ ${ }^{1}$ Ovidius University of Constanta, Faculty of Pharmacy, 6 Capitan Al. Serbanescu Str., Constanta, Romania \\ ${ }^{2}$ Ovidius University of Constanta, Faculty of Dental Medicine, 7 llarie Voronca Str., Constanta, Romania
}

\begin{abstract}
The scope of this work is a phytochemical analysis and antioxidant activity assay of a Sempervivum ruthenicum Koch hydroethanolic extract. The hydroethanolic extract was prepared from the dried leaves of the plant by maceration in a water and methanol mixture (50:50 v/v). The total phenolic content of the extract was calculated to be $3.0501 \pm 0.0272 \mathrm{mg} / \mathrm{mL}$ and the total flavonoid content was determined in a concentration of $3.113 \pm 0.0394 \mathrm{mg} / \mathrm{mL}$. The HPLC-DAD analysis revealed phenolic acids and flavonoids, which were quantified. The most prevalent phenolic acids in the extracts were gallic and ellagic acids, with concentrations of $1.2443 \pm 0.0475 \mathrm{mg} / \mathrm{mL}$, respectively $0.6339 \pm 0.0026 \mathrm{mg} / \mathrm{mL}$. The heteroside astragalin was present in high concentration of $1.1934 \pm 0.0754 \mathrm{mg} / \mathrm{mL}$. The DPPH free radical scavenging assay revealed the EC50 value of the extract to be $2.5788 \pm 0.003 \mathrm{mg} / \mathrm{mL}$. These results suggest a good scavenging ability of the extract, which is due to the abundance of polyphenolic compounds. The antioxidant activity of the extract demonstrates a high scavenging ability at low doses. Sempervivum ruthenicum Koch shows a promising phytochemical profile that suggests it's use in pathological conditions that involve high oxidative stress.
\end{abstract}

Keywords: Sempervivum ruthenicum, HPLC-DAD, polyphenols, DPPH, antioxidant

During the last 20 years, phytotherapy has been gaining a special interest due to the vast abundance of natural compounds with pharmacological properties, that can be used either as substitutes for synthetic drugs or as complementary treatments in a wide variety of diseases. Natural compounds have the advantage of exhibiting fewer side effects than synthetic drugs and can also be used to obtain derivatives with enhanced pharmacological properties [1,2].

Sempevivum ruthenicum Koch (common Houseleek) is a variety of the genus Sempervivum (Crassulaceae) endemic to the Dobrogea region of Romania. The species is differentiated from other members of the genus by a characteristic red color at the base of its yellow petals [3]. The plant can only be found in dry, rocky terrains, having multiple adaptations in order to survive in an arid environment, such as succulent leaves and well developed roots.

Members of the Sempervivum family are well known in folk medicine, being used in a variety of disorders such as bacterial otitis, burn wounds and peptic ulcers [4-6]. Most sources mention the usage of either fresh leaf juice or decoctions, to obtain a pharmacological effect, however, no phytochemical analysis of this plant has been published apart from those made by Gomeyuk et al. $[7,8]$ that highlights the presence of polyphenolic compounds and flavonoids [9].

The quantitative analysis and total antioxidant capacity of a Sempervivum ruthenicum Koch ethanolic extract was presented in a previous study [10], highlighting the presence of both polyphenols and flavonoids. The aim of this work is to characterize a hydroethanolic extractin order to determine its polyphenol and flavonoid content, and to evaluate its antioxidant properties, noting the differences between the different solvents used in order to obtain the extracts.

\section{Experimental part Materials}

Plant material was harvested form the Cheile Dobrogei Park during flowering ( $20^{\text {th }}$ August - $10^{\text {th }}$ September). The plants were identified at the Pharmaceutical Botanic Department of the Faculty of Pharmacy, where a voucher specimen was preserved. All harvested plants had a mean diameter of $7.5 \mathrm{~cm} \pm 2 \mathrm{~cm}$. The leaves were removed from the stem and were air-dried at a constanttemperature of $25 \pm 2{ }^{\circ} \mathrm{C}$ and relative humidity of $50 \% \pm 10 \%$ for 6 months. After obtaining the dry plant material, the water content was calculated to be $87.75 \%$, according to the Romanian Pharmacopoeia $10^{\text {th }}$ Edition [11].

All reagents and standards used were purchased from Sigma-Aldrich (Sigma-Aldrich GMBH, Munich, Germany). All reagents used were of analytical quality.

\section{Preparation of the hydroethanolic extract}

Ten grams of dry plant material were ground into a fine powder and passed through a no. 7 sieve and were macerated in a water-ethanol mixture $(50-50 \mathrm{v} / \mathrm{v})$ in order to obtain a concentration of $100 \mathrm{mg} / \mathrm{mL}$ [12]. Maceration took place for 14 days, with daily stirring for 1 minute every 8 hours. The macerate was filtered through a Whatman paper ( 42 porosity) three times, until a brown, clear extract was obtained. The extract was conserved in a borosilicate glass container at $2-8^{\circ} \mathrm{C}$.

\section{Total phenolic content}

The method employed by Tekeli [13] with slight alterations was used to determine the total phenolic content of the hydroethanolic extract. Briefly, the standard curve of pyrogallol was draw by using 6 dilutions in absolute methyl alcohol $(0.05,0.1,0.5,1.0,2.6$ and $6 \mathrm{mg} / \mathrm{mL}) .100$ $\mu \mathrm{L}$ of each dilution were vortexed with $500 \mu \mathrm{L}$ double distilled water and $100 \mu \mathrm{L}$ Folin-Ciocalteu Reagent, allowing the mixture to stand for $6 \mathrm{~min}$. Afterwards, $1 \mathrm{~mL}$ 
sodium carbonate $7 \%$ and $500 \mu \mathrm{L}$ double distilled water were added to the reaction mixture, which was left at room temperature for $90 \mathrm{~min}$. The absorbance of the samples was read at $760 \mathrm{~nm}$ using a UV-Vis UV-6300PC (VWR) spectrophotometer. The plant extract was assayed according to the same procedure. The total phenolic content was calculated as pyrogallol equivalents (mgPIR/ $\mathrm{mL}$ ). The assay was done in triplicate, and all results are expressed as mean $\pm \mathrm{SD}$.

\section{Total flavonoid content}

Total flavonoid content was determined according to Chantiratikul et al. [14]. Quercetin was used as reference, and the total flavonoid content was determined as quercetin equivalents. A standard quercetin solution of $1 \%$ was prepared in absolute methanol, from which 6 dilutions were made: $0.05,0.1,0.5,1.0,2.5$ and $5 \mathrm{mg} / \mathrm{mL}$. $100 \mu \mathrm{L}$ of each dilution were vortexed with $500 \mathrm{uL}$ double distilled water and $100 \mu \mathrm{L}$ sodium nitrate $5 \%$, allowing the mixture to react for $6 \mathrm{~min}$. Afterwards, $150 \mu \mathrm{L}$ aluminum chloride solution (10\%) were added, allowing a reaction time of 5 minute and finally $200 \mu \mathrm{L}$ sodium hydroxide solution (1M) were added. The absorbance was read at $510 \mathrm{~nm}$ using a UV-Vis UV-6300PC (VWR) spectrophotometer. The plant extract was subjected to the same assay conditions. All experiments were done in triplicate, and the results are expressed as mean \pm SD.

\section{HPLC analysis}

To identify and quantify the bioactive compounds in the plant extract, a standardised HPLC method for determining phenolic compounds was used, described in the USP 30NF25 Pharmacopoeia [15].

The equipment used included a Agilent 1200 chromatogram with quaternary pump, DAD, thermostat, degas system and autosampler. The chromatographic column employed was a C18 Zorbax XDB $250 \mathrm{~mm}$ X 4.6 $\mathrm{mm} ; 5 \mu \mathrm{m}$. The eluents consisted of phosphoric acid $(A)$ $0.1 \%$ and acetonitrile (B), and employed a linear gradient as follows: $10 \%$ B for $13 \mathrm{~min}, 22 \% \mathrm{~B}$ for $1 \mathrm{~min}, 40 \% \mathrm{~B}$ for 3 $\mathrm{min}$ and $10 \% \mathrm{~B}$ for $1 \mathrm{~min}$. The column temperature was 35 ${ }^{\circ} \mathrm{C}$ and the flow rate was $1.5 \mathrm{~mL} / \mathrm{min}$. The injection volume was $20 \mu \mathrm{L}$ and the total elution time was $20 \mathrm{~min}$. Detection was carried out using the DAD system at $310 \mathrm{~nm}, 335 \mathrm{~nm}$ and $360 \mathrm{~nm}$, simultaneously. Standards used included: Eresveratrol, Z-resveratrol, caffeic acid, chlorogenic acid, cinnamic acid, ellagic acid, vanillin, gallic acid, ferulic acid, astragalin, isorhamnetin, kaempferol, scutellarin, rutoside and quercetin. The hydroethanolic extract vas injected 4 times (each injection noted by $I$ ). The results were expressed as mean \pm SD.

Determination of Antioxidant Activity Using the 2,2Diphenyl-1-picrylhydrazyl (DPPH) Radical Scavenging Method

The method used to determine the total antioxidant capacity of the Sempervivum ruthenicum Koch was described in a previous study [10]. Briefly, a $4 \% 2,2-$ diphenyl-1-picrylhydrazyl (DPPH) solution was prepared in absolute methanol and stored in the absence of light. Seven dilutions of plant extract were prepared, with concentrations ranging from $1 \mathrm{mg} / \mathrm{mL}$ to $100 \mathrm{mg} / \mathrm{mL}$. 100 $\mu \mathrm{L}$ test sample were mixed with $3.9 \mathrm{~mL}$ DPPH stock solution and the mixture was left to react in the absence of light for $30 \mathrm{~min}$. The absorbance was read at $517 \mathrm{~nm}$ using a UV-Vis UV-6300PC (VWR) spectrophotometer. A blank sample using a hydroethanolic mixture (50/50 v/v) was used as negative control. The total antioxidant capacity of the plant extract was calculated using the following equation (1):

$$
\% \text { SA } \frac{A_{\text {centol }} A_{\text {sanplo }}}{A_{\text {conval }}} \times 100
$$

Where $A$ is the absorbance measured at $517 \mathrm{~nm}$. The efficient concentration needed to inhibit $50 \%$ of the DPPH free radical (EC50) was calculated by linear interpolation [16]. All experiments were done in triplicate, and the results are expressed as mean \pm SD.

\section{Statistical analysis}

Results were expressed as mean \pm standard deviation. Statistical analysis was carried out using BM SPSS Statistics 17 (IBM IBM, Armonk, New York, NY, USA) by applying ANOVA. Significant differences among samples were evaluated by Tukey's test at a significance level of 0.05 .

\section{Results and discussions}

\section{Total phenolic and flavonoid content}

The total phenolic content of the analysed plant extract showed a value of $3.0501 \pm 0.0272 \mathrm{mg} / \mathrm{mL}$ and the total flavonoid content was determined at a value of $3.113 \pm 0.0394 \mathrm{mg} / \mathrm{mL}$. In a previous study conducted on the same plant species, we determined the total phenolic content of a pure ethanolic extract of Sempervivum ruthenicum Koch dried leaves [10] with a value of $1.0344 \pm 0.0237 \mathrm{mg} / \mathrm{mL}$. The solvent mixture used for extraction suggests a more effective recovery of phenolic compounds in comparison with absolute ethanol.

\section{HPLC analysis}

The HPCL analysis of the hydroethanolic plant extract revealed the presence of a number of polyphenols and flavonoids. The polyphenolic acids identified included gallic acid, chlorogenic acid, caffeic acid, $p$-coumaric acid, ferulic acid, cinnamic acid and ellagic acid. The compounds were also quantified, with the results presented in table 1.

A total concentration of $1.9892 \pm 0.0608 \mathrm{mg} / \mathrm{mL}$ polyphenolic acids was calculated from the results, accounting for $65.21 \%$ of the total phenolic compounds determined previously. The remainder of phenolic compounds have yet to be identified and quantified. Previous studies show the presence of phenolic acids both in Sempervivum ruthenicum Koch [10], as well as in other species of the genus [4-9]. These findings suggest that Sempervivum species represent a good source of natural

Table 1

POLYPHENOLIC ACIDS QUANTIFIED BY HPLC-DAD FROM A SEMPERVIVUM RUTHENICUM KOCH HYDROETHANOLIC EXTRACT

\begin{tabular}{|c|c|c|c|c|c|c|c|}
\hline & \multicolumn{7}{|c|}{ Polyphenolic acids (mg/mL) } \\
\cline { 2 - 8 } & $\begin{array}{c}\text { Gallic } \\
\text { acid }\end{array}$ & $\begin{array}{c}\text { Chlorogenic } \\
\text { acid }\end{array}$ & $\begin{array}{c}\text { Caffeic } \\
\text { acid }\end{array}$ & $\begin{array}{c}\text { Ferulic } \\
\text { acid }\end{array}$ & $\begin{array}{c}\text { Cinnamic } \\
\text { acid }\end{array}$ & $\begin{array}{c}\text { p-coumaric } \\
\text { acid }\end{array}$ & $\begin{array}{c}\text { Ellagic } \\
\text { acid }\end{array}$ \\
\hline $\begin{array}{c}\text { Mean } \\
\text { value }\end{array}$ & $\mathbf{1 . 2 4 4 3}$ & $\mathbf{0 . 0 0 7 3}$ & $\mathbf{0 . 0 1 8 3}$ & $\mathbf{0 . 0 4 5 0}$ & $\mathbf{0 . 0 1 4 2}$ & $\mathbf{0 . 0 2 5 8}$ & $\mathbf{0 . 6 3 3 9}$ \\
\hline $\begin{array}{c}\text { Standard } \\
\text { deviation }\end{array}$ & 0.0475 & 0.0007 & 0.0017 & 0.0019 & 0.0046 & 0.0015 & 0.0026 \\
\hline
\end{tabular}


Table 2

FLAVONOIDS QUANTIFIED BY HPLC-DAD FROM A SEMPERVIVUM RUTHENICUM KOCH HYDROETHANOLIC EXTRACT

\begin{tabular}{|c|c|c|c|c|c|c|}
\hline & \multicolumn{3}{|c|}{ Flavanols $(\mathrm{mg} / \mathrm{mL})$} & \multicolumn{2}{|c|}{ Heterosides (mg/mL) } & \multirow{2}{*}{$\begin{array}{r}\begin{array}{r}\text { Flavones } \\
\text { (mg/mL) }\end{array} \\
\text { Scutellarein }\end{array}$} \\
\hline & Kaempferol & Quercetin & Isorhamnetin & Astragalin & Rutoside & \\
\hline Mean & 0.2462 & 0.0499 & 0.0171 & 1.1934 & 0.1296 & 0.6264 \\
\hline $\begin{array}{l}\text { Standard } \\
\text { deviation }\end{array}$ & 0.0006 & 0.0038 & 0.0031 & 0.0754 & 0.0118 & 0.1034 \\
\hline
\end{tabular}

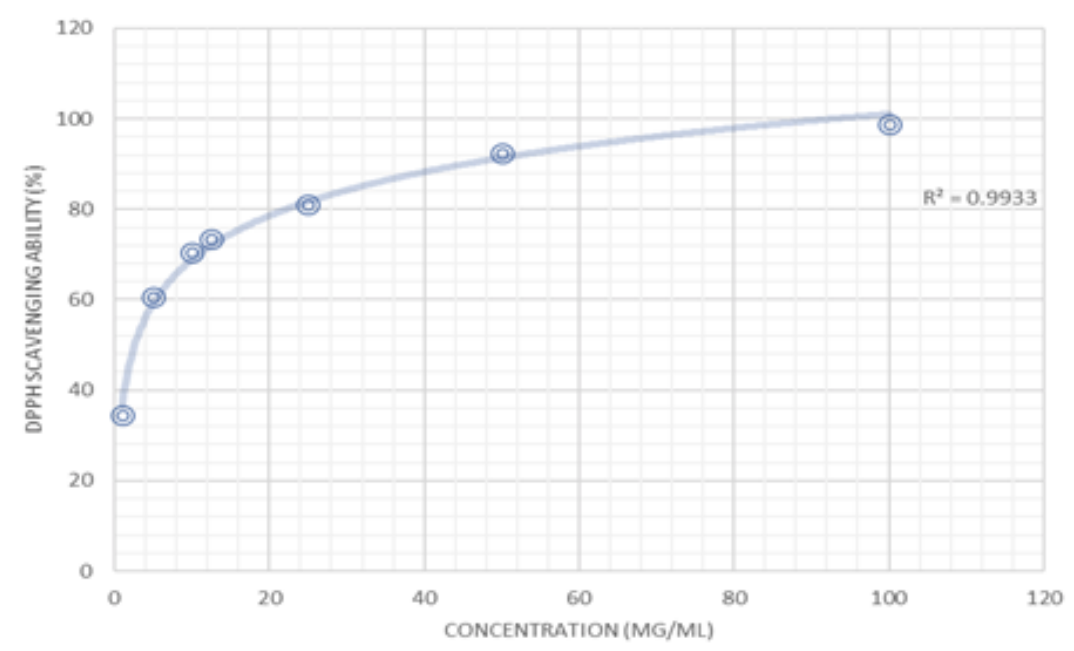

Fig. 1. Antioxidant activity of the Sempervivum ruthenicum Koch hydroethanolic extract

polyphenols. The main phenolic acid identified was gallic acid, with a concentration of $1.2443 \pm 0.0475 \mathrm{mg} / \mathrm{mL}$, which was also found in other similar studies [17].

The flavonoids identified and quantified by HPLC-DAD analysis include isorhamnetin, astragalin, kaempferol, quercetin, scutellarin, isorhamnetin and rutoside. The flavonoids were divided into three groups according to their chemical structure: flavanols (kaempferol, quercetin and isorhamnetin), heterosides (astragalin and rutoside) and flavones (scutellarein). The quantification of the identified flavonoids can be seen in table 2 .

The most prevalent flavonoid identified in the hydroethanolic extract was astragalin with a concentration of $1.1934 \pm 0.0754 \mathrm{mg} / \mathrm{mL}$. The presence of all identified flavonoids was confirmed in other Sempervivum species [17], however the exactconcentration of these compounds was not previously determined.

The biological activities of the compounds identified in Sempervivum ruthenicum Koch include anti-inflammatory $[5,18,19]$, antioxidant $[20,21]$, antimicrobial $[5,22]$ and immunomodulatory effects $[6,23]$. Both traditional medicine and current research suggest the potential use of Sempervivum species in pathological states that involve high oxidative stress and infections.

\section{DPPH Radical Scavenging Method}

The DPPH method is being used for nearly 50 years to evaluate the ability of a compound to act as a free radical scavenger or hydrogen donor, and also to evaluate its antioxidant capacity. The EC50 (efficient concentration value) is used to interpret the results of this method and is defined as the concentration of compound that causes $50 \%$ loss of the DPPH activity, which changes colour. The EC50 value of the hydroethanolic plant extract was $2.5788 \pm 0.003 \mathrm{mg} / \mathrm{mL}$. In comparison, our previous study [10] on the ethanolic extract of Sempervivum ruthenicum Koch revealed a EC50 value of $4.6112 \pm 0.08 \mathrm{mg} / \mathrm{mL}$ which was significantly higher. These values correlate with the total polyphenol content and total flavonoid content, suggesting that the mixture of solvents is more effective in recovering the antioxidant compounds from the dried plant material. Similar studies were carried out on different Sempervivum species, showing a good antioxidant potential [17]. Karabegovic et al. [24] have determined a EC50 value of $0.0246 \pm 0.45 \mathrm{mg} / \mathrm{mL}$ for a ultrasound assisted methanolic extract of $S$. tectorum, which highlights the high concentration of antioxidant compounds in the species, that can be recovered by more advanced extraction techniques. The authors showed that the extraction technique plays a key role in the recovery of antioxidant compounds, which is confirmed by the comparison between the antioxidant activity of the ethanolic and hydroethanolic extracts of Sempervivum ruthenicum Koch [10]. Figure 1 displays the DPPH radical scavenging activity of the Sempervivum ruthenicum Koch hydroethanolic extract.

\section{Conclusions}

The phytochemical characterization of Sempervivum ruthenicum Koch hydroethanolic extract shows the presence of polyphenolic acids and flavonoids with high concentrations of both types of compounds. The antioxidant activity of the extract demonstrates a high scavenging ability at low doses. Sempervivum ruthenicum Koch shows a promising phytochemical profile that suggests its use in pathological conditions that involve high oxidative stress.

\section{References}

1.CHEUKA, P.M., MAYOKA, G., MUTAI, P., CHIBALE, K, Molecules, 22, no. 58,2017, p. 1.

2.IORDANESCU, I.P., POPA, O., BANEANU, N., NITA, S., PARASCHIV, I., DOVRE, N., IONICA, I., Rev. Chim. (Bucharest), 66, no. 5, 2015, p. 634. 3.WILLIS, H., WILLIS, S., An Introduction to Sempervivum and J ovibarba Species and Cultivars, Howard and Sally Williams, 2004, p. 42.

4.ROVCANIN, B.R., CEBOVIC, T., STESEVIC, D., RISTIC, M., BiosCi. J., 31, no. 6, 2015, p. 1852.

5.STOJ COVIC, D., BARROS, L., PETROVIC, J., GLAMOCLIJA, J., SANTOS-BUELGA, C., FERREIRA, I.C.F.R., SOKOVIC, M., J. Ethnopharmacol., 176, p. 297. 
6.ALBERTI, A., BENI, S., LACKO, E., RIBA, P., AL-KHRASANI, M., KERY, A., J. Pharm. Biomed. Anal., 70, 2012, p. 143.

7.GUMENYUK, L.A., BATYUK, V.S., DYKHANOV, N.N., Chem. Nat. Compd., 8, no. 2, 1972, p. 242.

8.GUMENYUK, L.A., Chem. Nat. Compd., 7, no. 4, 1971, p. 503.

9.GUMENYUK, L.A., DYKHANOV, N.N., BATYUK V.S., Chem. Nat. Compd., 8, 3, 1972, 385.

10.MIHAI, S., RADU, M.D., POPESCU, A., RADUCANU, M., BADEA, V., NORDSCI Conference Proceedings, 1, 1, 2018, p. 485.

11.*** Farmacopeea Romana Editia a 10-a, Editura Medicala, Bucuresti, 2010, p. 1016.

12.SINGH, J, Extraction Technologies for Medicinal and Aromatic Plants, ICS UNIDO, Editors: Suckhdev Swami Handa, Suman Preet Singh Khanuja, Gennaro Longo, dev Dutt Rakesh, Trieste, 2008, p. 67. 13.TEKELI, Y., Rev. Chim.(Bucharest), 63, no. 5, 2012, p. 465.

14.CHANTIRATIKUL, P., MEECHAI, P., NAKBANPOTECC, W., Res J Biol Sci, 4, no. 10, 2009, p. 1113.

15.*** United States Pharmacopeia and National Formulary (USP 30 NF 25), 28, no. 4, Rockville, MD: United States Pharmacopeia Convention, 2007, p. 914.
16.PHAM, A.T., MALTERUD, K.E., PAULSEN, B.S., DIALLO, D., WANGENSTEEN, H., Nat. Prod. Commun., 8, no. 6, 2011, p. 1125.

17.UZUN, Y., DALAR, A., KONCZAK, I., Pharm. Biol., 55, no. 1, 2017, p. 532.

18.LI, F., WANG, W., CAO, Y., LIANG, D., ZHANG, W., ZHANG, Z., JIANG, H., GUO, M., ZHANG, N., J. Surg. Res., 192, 2014, p. 573.

19.SOROMOU, L.W., CHEN, N., HUO, M., WEI, M., CHU, X., MILLIMOUNO, F.M., FENG, H., SIDIME, Y., DENG, X., Biochem. Biophys. Res. Commun., 419, 2012, p. 256.

20.RAJAN, V.K., MURALEEDHARAN, K., Food Chem., 220, 2017, p. 93. 21.KILIC, I., YESILOGLU, Y., BAYRAK, Y., Spectrochim Acta A Mol Biomol Spectrosc., 130, 2014, p. 447.

22.DONNE, M.L., LENTINI, M., ALIBRANDI, A., SALIMBENI, V., GIUFFRE, G., MAZZEO, F., TRIOLO, O., D'ANNA, R., J. Funct. Foods, 35, 2017, p. 549.

23.BURMISTROVA, O., QUINTANA, J., DIAZ, J.G., ESTEVEZ, F., Cancer Lett., 309, 2011, p. 71.

24.KARABEGOVIC, I.T., STOJ ICEVIC, S.S., VELICKOVIC, D.T., NIKOLIC, N.C., LAZIC, M.L., Hem. Ind., 72, no. 1, 2018, p. 17.

Manuscript received: 10.09 .2018 